\title{
COMPARISON BETWEEN SUTURE AND FIBRIN ADHESIVE DERIVED FROM SNAKE VENOM FOR FIXATION OF CONNECTIVE TISSUE GRAFT IN CORRECTION OF MARGINAL TISSUE RECESSION
}

THESIS: G.C.M. Chiquito submitted this thesis for her Doctorate on General Basis of Surgery - Repair ad Regeneration of Tissues and Organs at Botucatu School of Medicine, São Paulo State University, UNESP, Botucatu, São Paulo, Brazil, 2006.

Advisor: Professor Luiz Eduardo Naresse.

ABSTRACT: The present study aimed at evaluating the postoperative characteristics of exposed root surfaces treated with connective tissue graft by using two fixation techniques. Forty-two patients were randomly divided into two groups of 21 individuals each. In the first group (test group), graft was fixed to exposed root surfaces by using fibrin adhesive derived from snake venom; in the second group (control group), conventional suture procedures were employed. The patients' age ranged from 19 and 49 years old and they presented a gingival defect known as marginal tissue recession (Miller's class I and class II). Clinical parameters such as surgical time, hemostasis time, presence of erythema, breath and taste alterations, root coverage degree, recession height, vestibular probing depth, clinical insertion level, plaque index, gingival index, amount of attached gingiva, keratinized tissue and aesthetics were assessed on the preoperative and trans-operative periods, and 7 , $14,21,30,60$ and 90 days postoperative. Comparative analysis between the initial and final moments of each group showed statistically significant results for all variables evaluated, mainly at the end of the study. Comparison of groups showed statistically significant results for surgical time, amount of attached gingiva, and vestibular probing depth; test group presented better results. No significant differences were observed for the other variables including aesthetics. Fibrin adhesive derived from snake venom showed favorable characteristics when applied in periodontal surgery for root coverage in marginal tissue recessions (Miller's class I and class II), and was an efficient substitute for conventional suture.

KEY WORDS: fibrin glue, root coverage, connective tissue graft, marginal tissue recession, periodontal surgery.

CORRESPONDENCE TO:

GESILDA CORREIA DE MELO CHIQUITO, Rua Aviador Mário Fundagem Nogueira, 3-18, Jardim América, 17017-324, Bauru, SP, Brasil. Email: gc-chiquito@uol.com.br. 